\title{
Pengaruh Iklim Organisasi dan Kemampuan Kerja Terhadap Komitmen Organisasional dan Dampaknya Pada Kinerja Pegawai DISPERINDAGKOP dan UKM Kota Pontianak
}

\author{
Yessi Mailisa \\ Pemerintah Kota Pontianak \\ M. Irfani Hendri* \\ Universitas Tanjungpura \\ Rizky Fauzan \\ Universitas Tanjungpura
}

\begin{abstract}
This research aims to determine the effect of organizational climate and work ability towards organizational commitment and its impact on the employee performance. Endogenous variable in this research is the performance of employees, while, the exogenous variables are the organizational climate and work ability. This research proposes organizational commitment to be the intervening variable. This research using a 55 samples who are taken from the employees of Perindagkop and SMEs in Pontianak City. The type of research was a descriptive survey research with questionnaire as the main data collecting media. Method of sampling in this research is census method where the entire population being sampled. Data were analyzed using path analysis (Path Analysis) facilitated by SPSS for Windows 22.0. The results showed that the organizational climate and the ability to work in a positive and significant effect on organizational commitment and the performance of employees. In contrast, the variable organizational commitment has no significant effect to employee performance. It means that organizational commitment to the organization of the Perindagkop and SMEs Pontianak City has no effect on employee performance improvement.
\end{abstract}

Keyword: Organizational climate, work ability, organizational commitment, and employee performance.

\section{PENDAHULUAN}

Pengelolaan Pemerintahan tidak terlepas dari peran aparatur pemerintah sebagai pelaksana pemerintahan. Pemerintahan dapat berjalan dengan baik bila pemerintah memiliki aparatur berkualitas dan profesional dalam menjalankan tugas dan tanggung

\footnotetext{
* Korespondensi: M. Irfani Hendri, Jurusan Manajemen, Fakultas Ekonomi dan Bisnis, Universitas Tanjungpura, Jalan Prof. DR. H. Hadari Nawawi, Pontianak 78124, Indonesia. Email:
} 
jawabnya. Tugas dan tanggung jawab instansi pemerintah meliputi fungsi pelayanan, pemerintahan, dan pembangunan. Pemerintah Kota Pontianak terus melakukan perbaikan pada kinerja pegawainya dengan meningkatkan kualitas sumber daya manusia dan menerapkan good governance dalam penyelenggaraan pemerintahan.

Dinas Perindustrian, Perdagangan, Koperasi dan UKM Kota Pontianak (Disperindagkop dan UKM) merupakan unsur pelaksana teknis bidang Perindustrian, Perdagangan, Koperasi dan UKM dalam memberikan pelayanan kepada masyarakat berupa layanan perizinan usaha industri kecil dan menengah, usaha perdagangan, pelayanan terhadap pedagang di pasar-pasar tradisional serta pelayanan terhadap koperasi dan UKM.

Dilihat dari struktur organisasi pembagian kerja tentang tugas, pokok dan fungsi pelayanan Dinas Perindagkop dan UKM kepada masyarakat telah jelas, oleh karenanya sumber daya manusia yang ada harus terus melakukan pembaharuan. Tetapi, tidak semua pegawai menyambut pembaharuan dengan positif. Terdapat pula pegawai yang belum perduli terhadap pembaharuan yang ada, dilihat dari pencapaian kinerja organisasi terdapat penurunan pada Tahun 2012, dimana persentase pencapaian hanya sebesar $91 \%$.

Tidak tercapainya target kinerja kelembagaan dapat dikarenakan faktor eksternal dan internal organisasi. Faktor eksternal lebih disebabkan oleh kebijakan dari pemerintah pusat yang berubah-ubah, kondisi sosial politik, pelaku usaha dan lain-lain. Sedangkan faktor internal organisasi dapat disebabkan karena lingkungan kerja yang kurang kondusif, menurunnya tingkat kehadiran pegawai, terbatasnya sumber daya aparatur dan sarana prasarana kantor yang belum cukup memadai. Masalah di atas perlu mendapatkan perhatian karena dapat mempengaruhi kinerja pegawai menjadi kurang optimal.

Pada umumnya kinerja diartikan sebagai kesuksesan seseorang dalam melaksanakan suatu pekerjaan. Menurut Mangkunegara (2011) kinerja adalah hasil kerja secara kualitas dan kuantitas yang dicapai oleh seorang pegawai dalam melaksanakan tugasnya sesuai dengan tanggung jawab yang diberikan kepadanya. Banyak faktor yang dapat mempengaruhi kinerja, antara lain: motivasi, kemampuan, kesempatan (Robbins, 2006). Sumber daya manusia akan selalu mengalami perubahan dan perkembangan. Pengelolaan sumber daya manusia yang baik sangat penting dalam pencapaian tujuan organisasi.

Sumber daya manusia dalam hal ini aparatur pemerintah yang ada dalam suatu organisasi atau unit kerja merupakan faktor utama dalam menggerakkan organisasi. Dimana keberhasilan sebuah organisasi dalam mencapai visi dan misi sangat tergantung dari kualitas sumber daya manusia yang dimiliki. Visi dan misi suatu organisasi dapat terlaksana bila sumber daya manusianya memiliki kemampuan kerja yang tinggi. Kemampuan kerja yang tinggi dapat dimiliki seorang pegawai jika memiliki pengetahuan dan pendidikan yang memadai sehingga dapat lebih mudah dalam 
menjalankan tugasnya. Oleh karenanya, pegawai sebaiknya ditempatkan pada pekerjaan yang sesuai dengan keahlian yang dimiliki.

Kinerja yang tinggi juga dapat tercapai jika iklim suatu organisasi baik, karena dengan iklim organisasi yang baik, setiap individu, tim kerja dan pimpinan, akan mengetahui, memahami dan melaksanakan tata kerja sesuai tugas, fungsi, pekerjaan, kedudukan, hak dan kewajiban, komunikasi, serta wewenang dan tanggung jawabnya sehingga diharapkan semakin meningkat kinerja pegawai.

Menurut Adryanto (2014), kinerja seseorang itu dipengaruhi oleh 3 (tiga) faktor utama yaitu kemampuan, motivasi dan lingkungan. Iklim suatu organisasi dapat dinilai baik jika pegawai merasa nyaman berada di lingkungan organisasi dan mempengaruhi pegawai tersebut dalam mencapai kinerja yang diharapkan. Iklim organisasi Dinas Perindagkop dan UKM pada umumnya dinilai cukup baik, tetapi masih terdapat kekurangan dalam hal koordinasi internal antar bidang, permasalahan lainnya adalah tingkat kehadiran pegawai, seperti yang dikemukakan oleh Manthis dan Jackson (2001) tingkat ketidakhadiran dan masuk keluarnya tenaga kerja menggambarkan loyalitas pegawai. Pada kenyataannya di Dinas Perindagkop dan UKM Kota Pontianak tingkat ketidakhadiran pegawainya perlu menjadi perhatian karena dapat mempengaruhi kinerja pegawai itu sendiri.

Menurut Sopiah (2008), komitmen organisasional adalah keinginan anggota organisasi untuk tetap mempertahankan keanggotaannya dalam organisasi dan bersedia berusaha keras bagi pencapaian tujuan organisasi. Komitmen organisasional pegawai maupun komitmen pegawai pada organisasinya sangat diperlukan karena melalui komitmen itulah akan tercipta kinerja pegawai yang optimal.

Secara garis besar dapat dinyatakan bahwa iklim organisasi, kemampuan dan komitmen organisasional sangat penting artinya bagi pegawai secara keseluruhan, dengan iklim organisasi yang kondusif dan kemampuan kerja yang tinggi maka diharapkan dapat berpengaruh positif terhadap komitmen organisasional sebagai variabel antara yang dapat mendorong pencapaian kinerja yang optimal.

\section{TINJAUAN PUSTAKA}

\subsection{Iklim Organisasi}

Owen dalam Wirawan (2008) mendefinisikan iklim organisasi sebagai persepsi individu mengenai berbagai aspek lingkungan organisasinya. Lebih lanjut Wirawan (2008) mengemukakan bahwa iklim organisasi adalah persepsi anggota organisasi (secara individual dan kelompok) dan mereka yang secara tetap berhubungan dengan organisasi (misalnya pemasok, konsumen, konsultan dan kontraktor) mengenai apa yang ada atau terjadi di lingkungan internal organisasi secara rutin, yang mempengaruhi sikap 
dan perilaku organisasi serta kinerja anggota organisasi yang kemudian menentukan kinerja organisasi.

Pengaruh iklim organisasi terhadap perilaku organisasi dapat bersifat positif dan dapat bersifat negatif. Selanjutnya Stringer dalam Wirawan (2008) berpendapat bahwa iklim organisasi berfokus pada persepsi-persepsi yang masuk akal atau dapat dinilai, terutama yang memunculkan motivasi, sehingga mempunyai pengaruh langsung terhadap kinerja anggota organisasi. Stringer dalam Wirawan (2008) berpendapat untuk mengukur iklim organisasi terdapat enam dimensi yang diperlukan. Enam dimensi tersebut, antara lain struktur, standar-standar, tanggung jawab, dukungan dan komitmen.

\subsection{Kemampuan Kerja}

Suatu organisasi termasuk organisasi pemerintah daerah menuntut adanya aparatur atau perangkat daerah yang berkemampuan. Kemampuan sangat berguna untuk membantu organisasi menciptakan budaya kinerja tinggi. Kemampuan individu sebagai nilai yang dimiliki aparatur daerah menjadikan suatu kekuatan dalam menanggapi setiap kejadian - kejadian atau persoalan di lingkungan pekerjaan (Perdana, 2012). Kemampuan individu yang terbentuk dengan baik akan memberikan pengaruh positif dengan kinerja organisasi. Widodo (2004) menyatakan bahwa dalam menyelenggarakan pemerintahan, pemba-ngunan dan pelayanan masyarakat, maka memerlukan kemampuan dan kecakapan tinggi (profesionalisme) dengan beberapa persyaratan.

Menurut Robbins dalam Siregar (2014), kemampuan seseorang akan ditentukan oleh tinggi rendahnya tingkat pendidikan dan pengalaman. Sehingga dapat disimpulkan bahwa yang dimaksud dengan kemampuan pegawai dalam penelitian ini adalah semua potensi yang dimiliki pegawai untuk melaksanakan tugas berdasarkan pengetahuan, sikap, pengalaman, dan pendidikan.

Tingkat pendidikan, pengetahuan dan pengalaman yang rendah akan berdampak negatif pada kinerja pegawai. Sehingga pegawai pemerintah dituntut untuk memiliki kualifikasi tertentu, karena tidak semua orang memiliki keahlian yang dipersyaratkan untuk menyelesaikan pekerjaan. Rendahnya kinerja pegawai karena rendahnya kemampuan pegawai.

Dari uraian di atas dapat disimpulkan bahwa kemampuan pegawai akan menentukan kinerja organisasi. Dengan kata lain semakin tinggi kemampuan pegawai dalam melaksanakan pekerjaannya maka semakin tinggi kinerja pegawai. Kemampuan kerja merupakan salah satu unsur dalam kematangan berkaitan dengan pengetahuan atau ketrampilan yang dapat diperoleh dari pendidikan, pelatihan dan suatu pengalaman (Thoha, 2003). Untuk mengukur kemampuan aparat dalam penguasaan pengetahuan dapat dilihat dari:

1. Tingkat pendidikan formal yang pernah ditempuh. 
2. Tingkat pendidikan non formal (kursus, latihan, penataran dan lain- lain)

3. Tingkat perjalanan kerja yang dimiliki.

4. Tingkat keinginan/kemauan/minat pegawai terhadap ilmu pengetahuan dan perkembangan.

\subsection{Komitmen Organisasional}

Manthis dan Jackson dalam Sopiah (2008) memberikan definisi komitmen organisasional adalah derajat yang mana karyawan percaya dan menerima tujuan-tujuan organisasi dan akan tetap tinggal atau tidak akan meninggalkan organisasi. Komitmen organisasional adalah keinginan anggota organisasi untuk tetap mempertahankan keanggotaannya dalam organisasi dan bersedia berusaha keras bagi pencapaian tujuan organisasi.

Robbins, Allen and Meyer dalam Luthans (2006) menyatakan bahwa komitmen organisasional sebagai sebuah keadaan psikologi yang mengkarakteristikkan hubungan karyawan dengan organisasi atau implikasinya yang mempengaruhi apakah karyawan akan tetap bertahan dalam organisasi atau tidak, yang teridentifikasi dalam tiga komponen yaitu:

1. Komitmen afektif (affective commitment), yaitu: keterlibatan emosional seseorang pada organisasinya berupa perasaan cinta pada organisasi.

2. Komitmen berkelanjutan (continuance commitment), yaitu: persepsi seseorang atas biaya dan resiko dengan meninggalkan organisasi saat ini. Artinya, terdapat dua aspek pada komitmen berkelanjutan, yaitu: melibatkan pengorbanan pribadi apabila meninggalkan organisasi dan ketiadaan alternatif yang tersedia bagi orang tersebut.

3. Komitmen normatif (normative commitment), yaitu: sebuah dimensi moral yang didasarkan pada perasaan wajib dan tanggung jawab pada organisasi yang mempekerjakannya.

Komitmen organisasional memberi titik berat pada kekontinuan yang menyarankan untuk tetap atau meninggalkan organisasi yang pada akhirnya tergambar dalam statistik ketidakhadiran dan masuk keluarnya tenaga kerja dikemukakan oleh Manthis dan Jackson (2001).

\subsection{Kinerja Karyawan}

Kinerja dapat diartikan sebagai gambaran mengenai tingkat pencapaian pelaksanaan suatu kegiatan atau program atau kebijakan dalam mewujudkan sasaran, tujuan, misi dan visi organisasi yang tertuang dalam rencana strategi suatu organisasi (Lubis, 2012). Istilah kinerja sering digunakan untuk menyebut prestasi atau tingkat keberhasilan individu atau kelompok individu. 
Kinerja juga dapat diartikan sebagai hasil kerja yang dapat dicapai oleh seseorang atau kelompok orang dalam suatu organisasi sesuai wewenang dan tanggung jawab masing-masing, dalam rangka untuk mencapai tujuan organisasi yang bersangkutan. Kinerja pada dasarnya merupakan hasil kerja secara kualitas dan kuantitas yang dicapai seorang pegawai dalam melaksanakan tugasnya sesuai tanggung jawab yang diberikan kepadanya menurut Dharmawan (2013).

Penciptaan pekerjaan yang menantang akan menarik keinginan intrinsik yang dimiliki orang untuk menangani pekerjaannya dan menghindari rasa bosan, kegiatankegiatan yang melelahkan yang menghasilkan sedikit hasil positif. Mengenai ukuranukuran kinerja pegawai, Mangkunegara (2011) menjelaskan secara rinci sejumlah aspek yang meliputi:

1. Kualitas kerja adalah mutu hasil kerja yang didasarkan pada standar yang ditetapkan. Kualitas kerja diukur dengan indikator ketepatan, ketelitian, keterampilan dan kebersihan kerja. Kualitas kerja meliputi ketepatan, ketelitian, kerapihan dan kebersihan hasil pekerjaan.

2. Kuantitas kerja yaitu banyaknya hasil kerja sesuai dengan waktu kerja yang ada, yang perlu diperhatikan bukan hasil rutin tetapi seberapa cepat pekerjaan dapat terselesaikan. Kuantitas kerja meliputi output, serta perlu diperhatikan pula tidak hanya output yang rutin saja, tetapi juga seberapa cepat dia dapat menyelesaikan pekerjaan yang ekstra.

3. Dapat tidaknya diandalkan termasuk dalam hal ini yaitu mengikuti instruksi, inisiatif, rajin, serta sikap hati-hati.

4. Sikap, yaitu sikap pegawai terhadap perusahaan dan pekerjaan serta kerjasama dengan pegawai yang lainnya.

\subsection{Penelitian Empirik Terdahulu}

Penelitian terdahulu telah banyak dilakukan yang berkaitan dengan pengaruh iklim organisasi, kemampuan kerja, terhadap komitmen organisasional dan dampaknya pada Kinerja Pegawai. Penelitian yang dilakukan oleh Rofiatun \& Masluri (2011), misalnya, yang menguji pengaruh iklim organisasi dan kompetensi pegawai terhadap kinerja pegawai dengan mediasi motivasi pada dinas-dinas di Kabupaten Kudus. Dengan mempergunakan jumlah sampel yang digunakan sebanyak 110 responden dan analisis Struktural Equation Modelling (SEM) sebagai metode analisis data, mereka menemukan bahwa iklim organisasi dan kompetensi dengan mediasi motivasi terhadap kinerja memiliki pengaruh yang signifikan terhadap kinerja.

Suaraningsih, Alamsyah \& Thayib (2013) melakukan uji Path Analysis pada data yang diperoleh dari 81 responden untuk mengetahui pengaruh iklim organisasi terhadap komitmen organisasional dan kinerja karyawan di rumah sakit dan memperoleh hasil bahwa iklim Organisasi berpengaruh positif dan signifikan terhadap komitmen 
organisasional maupun kinerja karyawan. Drajat (2014) juga meneliti pengaruh kemampuan kerja dan iklim organisasi terhadap kinerja pegawai. Dengan mempergunakan data survey dari 99 orang responden yang diperoleh dari metode stratified random sampling, Hasil penelitiannya menunjukkan bahwa kemampuan dan iklim organisasi secara bersama-sama berpengaruh positif dan signifikan terhadap kinerja pegawai. secaara parsial, kemampuan dan iklim organisasi berpengaruh secara signifikan. Dengan variabel kemampuan yang memiliki pengaruh paling dominan untuk meningkatkan kinerja pegawai.

Penelitian mengenai topik ini juga ditemukan dari studi kasus di negara lainnya, seperti Nigeria dan Turki. Osa \& Amos (2014) meneliti pengaruh komitmen organisasi terhadap produktivitas kerja karyawan sehingga perlu dikaji secara empiris bagaimana dampak komitmen organisasi pada karyawan dalam menghadapi produktivitas karyawan. Komitmen organisasi untuk karyawan dapat digunakan untuk memperoleh dukungan karyawan bagi organisasi dan pada gilirannya memaksimalkan manfaat yang terima dari mereka karyawan dengan produktivitas yang lebih besar dan kinerja individu tampaknya meningkat dalam proporsi yang sama. Populasi penelitian terdiri dari 200 anggota staf dari Nigeria Brewery Plc di kantor pusat, teknik stratified random sampling digunakan untuk memilih ukuran sampel. Hasil penelitian mereka menunjukkan bahwa komitmen organisasi kepada karyawan memiliki dampak yang signifikan terhadap kinerja. Bahwa komitmen karyawan pada organisasi signifikan terhadap produktivitas organisasi. Motivasi memiliki pengaruh yang signifikan terhadap produktivitas karyawan, karena akan meningkatkan semangat kerja karyawan. Perbaikan struktural dalam sebuah perusahaan memiliki pengaruh signifikan terhadap pemenuhan karyawan.

Penelitian yang dilakukan oleh Zincirkiran, Emhan \& Yasar (2015) bertujuan untuk menguji efek dari kerja sama tim dan komitmen organisasi pada kinerja organisasi sektor kesehatan di Turki. Dalam penelitian ini, model yang diperkenalkan diuji dengan instrumen kuesioner dengan 27 item tidak termasuk variabel demografis. Studi ini difokuskan pada karyawan rumah sakit umum dan swasta di Diyarbakir. Hasil penelitian mereka menunjukkan bahwa ada hubungan linear positif antara kerja tim, komitmen organisasi danvariabel kinerja organisasi. Penelitian ini menunjukkan bahwa karyawan rumah sakit swasta memilikikerja sama tim yang lebih tinggi, komitmen dan kinerja organisasi skor dari karyawan rumah sakit umum.

Zhang \& Liu (2010) meneliti karakteristik iklim organisasi dan dampaknya pada variabel organisasi. Investigasi dari 419 peserta termasuk kedua manajer dan karyawan. Mereka menemukan bahwa tingkat pendidikan, posisi dan lamanya waktu bekerja untuk perusahaan saat ini memiliki efek utama pada iklim organisasi. Dibandingkan dengan individu dengan tingkat pendidikan tinggi, persepsi individu dengan tingkat pendidikan rendah untuk aturan, kinerja, promosi dan komunikasi lebihpositif; persepsi mereka tentang iklim organisasi juga lebih positif dengan naik dari posisi; mengenai gaji dan penghargaan. Secara khusus, karakteristik perusahaan dan ukuran perusahaan memiliki 
efek utama terhadap iklim organisasi. Karakteristik perusahaan memiliki dampak yang signifikan terhadap persepsi kinerja, gaji dan kesejahteraan. 3 macam iklim secara signifikan lebih unggul daripada di perusahaan milik negara. Ukuran perusahaan signifikan terhadap persepsi kepemimpinan, aturan, gaji dan kesejahteraan iklim.Iklim organisasi memiliki efek signifikan pada kinerja manajemen sumber daya manusia.Analisis regresi berganda menemukan bahwa kinerja, gaji dan pengembangan memiliki prediksi yang signifikanlamanya waktu bekerja untuk perusahaan saat ini, dan iklim organisasi memiliki efek signifikan terhadap efektivitas organisasi.

\subsection{Model Dan Hipotesis Penelitian}

Kerangka konseptual yang diajukan untuk penelitian ini berdasarkan pada hasil studi teoritik dan studi empirik teoritis dapat dilihat pada Gambar 1.

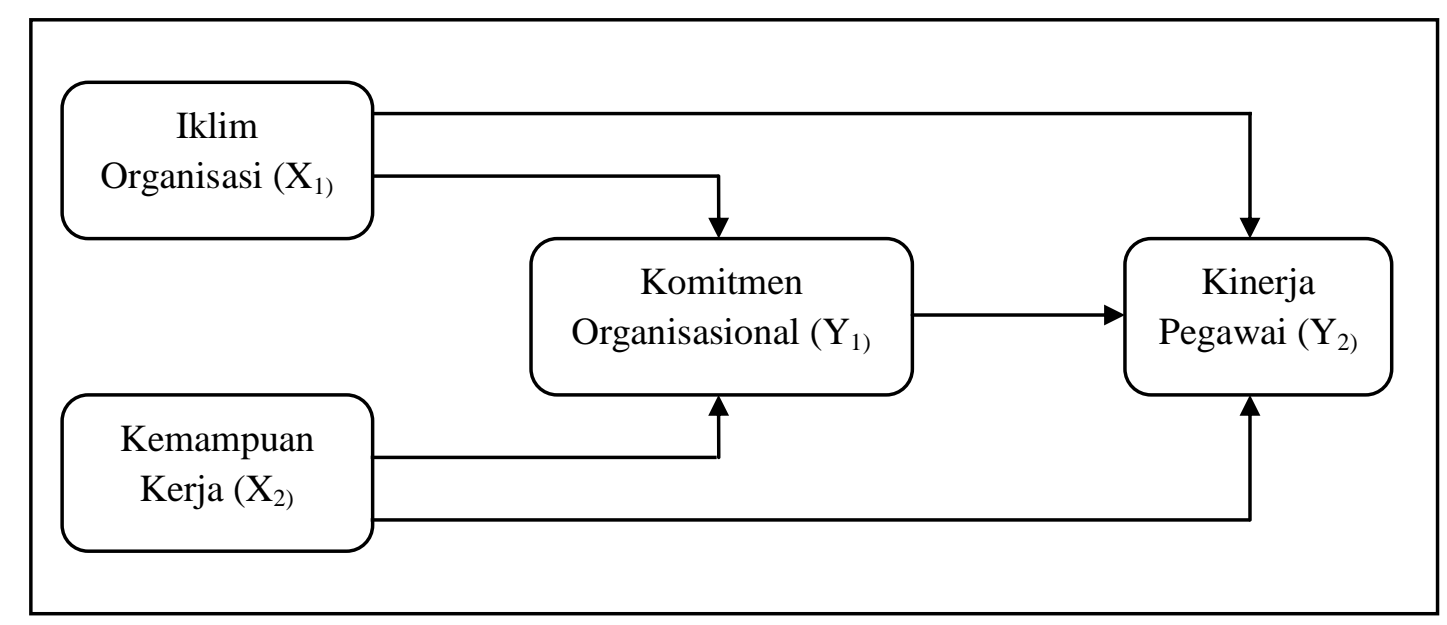

\section{Gambar 1 Model Penelitian}

Untuk melakukan pengujian model penelitian, terlebih dahulu penelitian ini merumuskan hipotesis sebagai berikut.

Hipotesis 1 : Iklim Organisasi berpengaruh signifikan terhadap Komitmen Organisasional pegawai Disperindagkop dan UKM Kota Pontianak.

Hipotesis 2: Iklim Organisasi berpengaruh signifikan terhadap Kinerja Pegawai Disperindagkop dan UKM Kota Pontianak.

Hipotesis 3: Kemampuan Kerja berpengaruh signifikan terhadap Komitmen Organisasional pegawai Dinas Perindagkop dan UKM Kota Pontianak.

Hipotesis 4: Kemampuan Kerja berpengaruh signifikan terhadap Kinerja Pegawai Dispperindagkop dan UKM Kota Pontianak. 
Hipotesis 5: Komitmen Organisasional berpengaruh signifikan terhadap Kinerja Pegawai Disperindagkop dan UKM Kota Pontianak.

\section{METODE PENELITIAN}

Jenis penelitian ini adalah penelitian kuantitatif dengan bentuk penelitian survei. Populasi dalam penelitian ini adalah pegawai Disperindagkop dan UKM Kota Pontianak yang berjumlah 55 orang. Sampel dalam penelitian ini adalah seluruh pegawai Disperindagkop dan UKM Kota Pontianak atau menggunakan metode sensus.

Pengumpulan data yang akan digunakan dalam penelitian ini dilakukan dengan mempergunakan observasi dan kuesioner (Umar, 2004). Metode pengumpulan data dengan observasi dilakukan tanpa terstruktur, artinya lebih fleksibel dan terbuka dimana peneliti dapat melihat kejadian secara langsung pada tujuannya. Sedangkan, metode pengumpulan data melalui kuesioner dilakukan dengan cara membuat pernyataanpernyataan dan kolom-kolom isian yang sesuai dengan sasaran penelitian dan diserahkan kepada para responden. Teknik pengukuran indikator variabel menggunakan kuesioner dengan skala likert, dimana skala ini digunakan untuk mengukur tingkat persetujuan atau ketidaksetujuan pegawai terhadap serangkaian pertanyaan yang mengukur variabelvariabel (Istijanto, 2010).

Variabel penelitian yang diajukan dalam penelitian ini terdiri atas variabel eksogen, variabel endogen dan variabel perantara (intervening). Variabel eksogen berfungsi sebagai variabel bebas atau variabel bergerak, yaitu variabel yang menjadi sebab terjadinya/terpengaruhnya variabel endogen. Dalam penelitian ini yang merupakan variabel eksogen adalah Iklim Organisasi $\left(\mathrm{X}_{1}\right)$ dan Kemampuan Kerja (X2). Variabel endogen berfungsi sebagai variabel terikat, yaitu variabel yang nilainya dipengaruhi oleh variabel eksogen. Dalam penelitian ini yang merupakan variabel endogen adalah Kinerja Pegawai (Y2). Variabel endogen perantara atau intervening secara teoritis adalah variabel yang mempengaruhi hubungan endogen dan eksogen menjadi hubungan langsung dan tidak langsung yang dapat diamati dan diukur. Dalam penelitian ini yang merupakan variable endogen perantara adalah Komitmen Organisasional ( $\left.\mathrm{Y}_{1}\right)$.

Adapun definisi operasionalisasi variabel penelitian dari masing-masing variabel adalah sebagai berikut:

a. Iklim organisasi $\left(\mathrm{X}_{1}\right)$ adalah persepsi-persepsi anggota organisasi yang masuk akal, terutama yang memunculkan motivasi sehingga mempunyai pengaruh langsung terhadap kinerja anggota organisasi (Stringer, 2002)

b. Kemampuan kerja $\left(\mathrm{X}_{2}\right)$ adalah merupakan salah satu unsur dalam kematangan berkaitan dengan pengetahuan atau ketrampilan yang dapat diperoleh dari pendidikan, pelatihan dan suatu pengalaman (Thoha, 2003)

c. Komitmen organisasional $\left(\mathrm{Y}_{1}\right)$ adalah adalah sebuah keadaan psikologi yang mengkarakteristikkan hubungan karyawan dengan organisasi atau implikasinya yang 
mempengaruhi apakah karyawan akan tetap bertahan dalam organisasi atau tidak (Allen \& Meyer, 1993)

d. Kinerja pegawai $\left(\mathrm{Y}_{2}\right)$ adalah hasil kerja secara kualitas dan kuantitas yang dicapai oleh seorang pegawai dalam melaksanakan tugasnya sesuai tanggung jawab yang diberikan kepadanya (Mangkunegara, 2011).

Teknik analisis data yang digunakan untuk menguji hipotesis adalah path analysis dengan tujuan untuk menguji dan menganalisis baik secara parsial maupun simultan untuk mengetahui pengaruh iklim organisasi, kemampuan kerja terhadap komitmen organisasional dan dampaknya pada kinerja pegawai Disperindagkop dan UKM Kota Pontianak.

\section{TEMUAN DAN PEMBAHASAN}

\subsection{Uji Normalitas}

Uji asumsi normalitas bertujuan untuk menguji apakah model regresi, variabel pengganggu atau residual memiliki distribusi normal atau tidak. Uji normalitas pada penelitian ini menggunakan scatter diagram. Distribusi normal akan membentuk satu garis lurus diagonal dan ploting data residual akan dibandingkan dengan garis diagonal. Jika distribusi data residual normal, maka garis yang menggambarkan data sesungguhnya akan mengikuti garis diagonalnya (Umar, 2004). Hasil pengujian dapat dilihat pada Gambar 2.

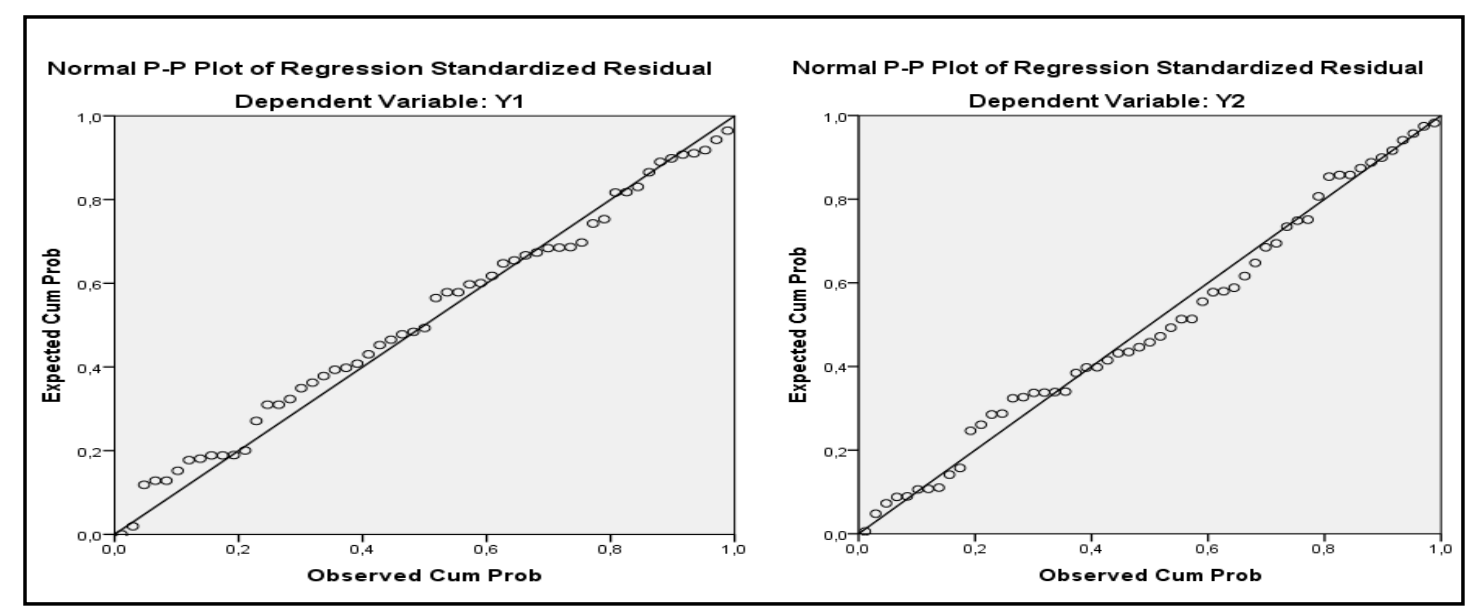

Gambar 2. Grafik Output Normal P-P Plot Terhadap Komitmen Organisasional

\subsection{Uji Linearitas}

Uji Linearitas bertujuan untuk melihat apakah spesifikasi model yang digunakan sudah benar atau tidak. Selain itu uji linearitas juga menguji apakah fungsi yang 
digunakan dalam suatu studi empiris sebaiknya berbentuk linear atau non linear. Hasil pengujian dapat dilihat pada Gambar 3.

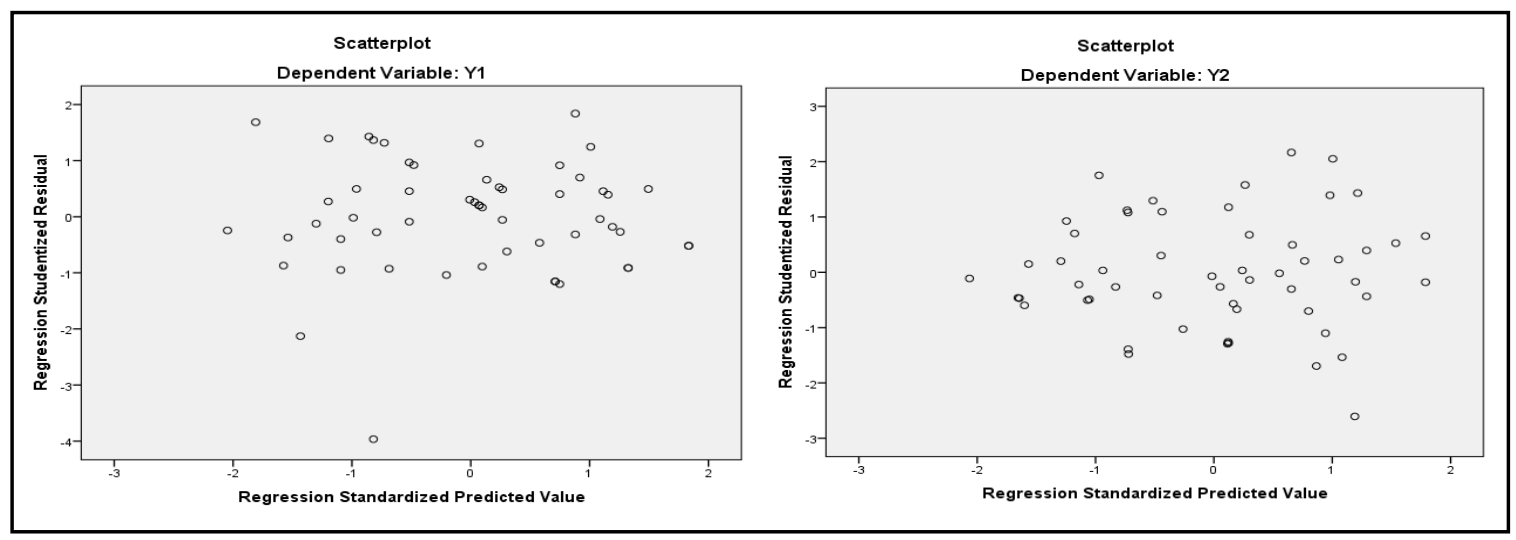

Gambar 3. Grafik Output Scatterplot Terhadap Kinerja Pegawai

\subsection{Analisis Jalur (Path Analysis)}

Pengujian hipotesis dilakukan dengan analisis jalur (path analysis). Path analysis merupakan perluasan dari analisis regresi berganda yang bertujuan untuk mengestimasi seberapa besar hubungan dan signifikansi hubungan antar beberapa variabel dengan melibatkan variabel perantara/intervening (Sugiyono, 2014).

Tabel 1. Output Coefficients Terhadap Komitmen Organisasional

\begin{tabular}{|c|c|c|c|c|c|}
\hline \multirow[b]{2}{*}{ Model } & \multicolumn{2}{|c|}{ Unstandardized Coefficients } & $\begin{array}{c}\text { Standardized } \\
\text { Coefficients }\end{array}$ & \multirow[b]{2}{*}{$\mathrm{t}$} & \multirow[b]{2}{*}{ Sig. } \\
\hline & $\mathrm{B}$ & Std. Error & Beta & & \\
\hline 1 (Constant) & -.395 & .438 & & -.902 & .371 \\
\hline $\mathrm{X} 1$ & .692 & .175 & .507 & 3.958 & .000 \\
\hline $\mathrm{X} 2$ & .449 & .169 & .340 & 2.659 & .010 \\
\hline
\end{tabular}

a. Dependent Variable: Y1

Tabel 2. Output Coefficients Terhadap Kinerja Pegawai

\begin{tabular}{|c|c|c|c|c|c|c|}
\hline & \multirow[b]{2}{*}{ Model } & Unstand & Joefficients & \multirow{2}{*}{$\begin{array}{c}\text { Standardized } \\
\text { Coefficients } \\
\text { Beta } \\
\end{array}$} & \multirow[b]{2}{*}{$\mathrm{t}$} & \multirow[b]{2}{*}{ Sig. } \\
\hline & & $\mathrm{B}$ & Std. Error & & & \\
\hline 1 & (Constant) & .407 & .175 & & 2.323 & .024 \\
\hline & $\mathrm{X} 1$ & .486 & .079 & .506 & 6.152 & .000 \\
\hline & $\mathrm{X} 2$ & .381 & .071 & .411 & 5.351 & .000 \\
\hline & Y1 & .070 & .055 & .100 & 1.278 & .207 \\
\hline
\end{tabular}

a. Dependent Variable: Y2 
Langkah pertama dalam dalam analisis jalur adalah merancang model berdasarkan konsep dan teori yang ada. Untuk membuat diagram jalur persamaan strukturalnya yang sesuai, diperlukan hasil analisis statistik regresi, seperti yang tertera pada Tabel 1 dan Tabel 2 di atas.

Berdasarkan hasil regresi pada Tabel 1 dan 2, diagram jalur persamaan struktural dapat digambarkan sebagai berikut:

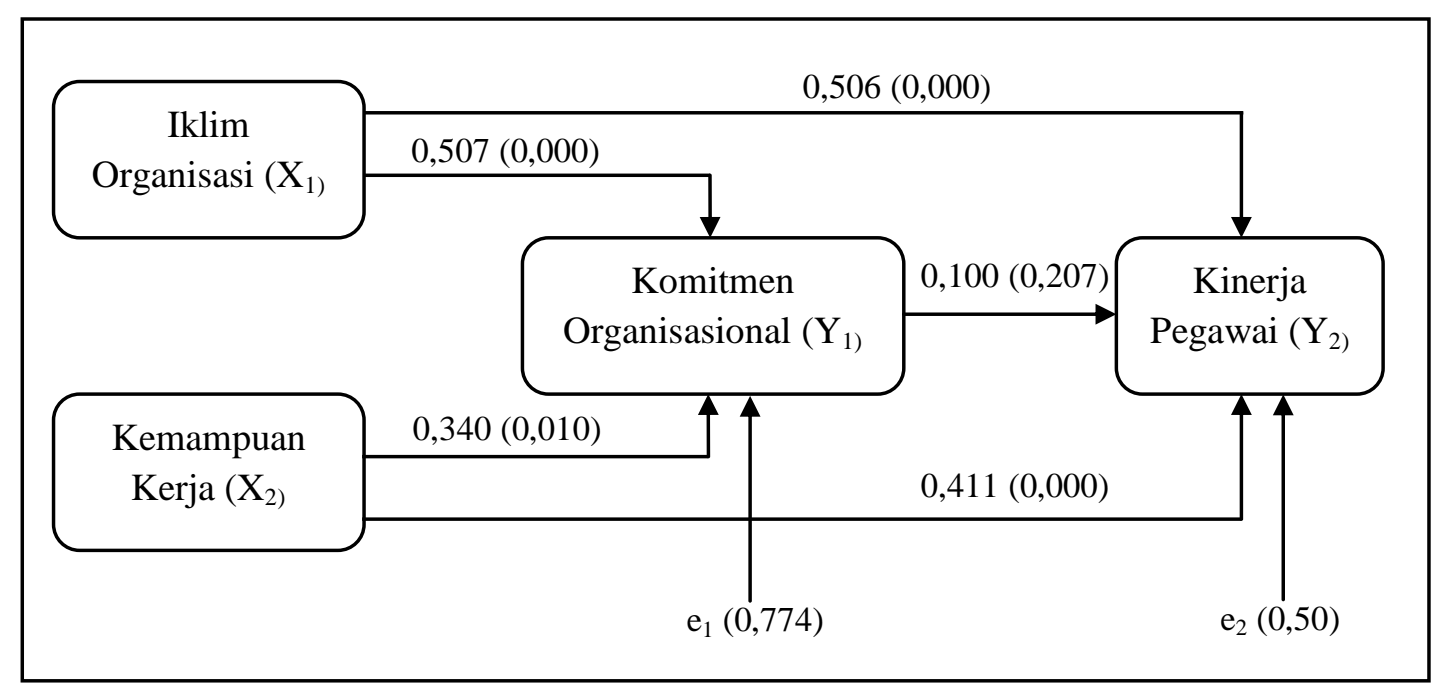

Gambar 4. Diagram Jalur Persamaan Struktural

Pemeriksaan terhadap asumsi-asumsi yang melandasi didapat hasil sebagai berikut. Pertama, hubungan antar variabel bersifat linier (time series tdk bisa) dan aditif. Dari Gambar 3, Scatterplot terlihat bahwa penyebaran residual adalah tidak membentuk pola tertentu/acak. Dapat disimpulkan bahwa antara variabel bebas dan variabel terikat terdapat hubungan yang linear (asumsi linearitas terpenuhi). Kedua, model penelitian bersifat hubungan searah (rekursif). Asumsi ini terpenuhi dilihat dari Gambar 4 dimana sifat hubungan tidak ada arah yang berbalik. Ketiga, variabel endogen minimal dalam skala interval. Asumsi ini terpenuhi, dimana pembobotan nilai dalam interval sama. Keempat, variabel diukur tanpa kesalahan (instrumen valid dan reliabel). Asumsi ini terpenuhi dengan hasil uji validitas dan reabilitas. Terakhir, model dianalisis dengan benar berdasarkan teori yang ada. Asumsi ini terpenuhi dimana hasil analisis dilihat berdasarkan teori.

Diagram jalur di atas mempunyai dua persamaan structural sebagai berikut:

$Y_{1}=\rho Y_{1} X_{1}+\rho Y_{1} X_{2}+e_{1}$

$\mathrm{Y} 2=\rho \mathrm{Y}_{2} \mathrm{X}_{1}+\rho \mathrm{Y}_{2} \mathrm{X}_{2}+\rho \mathrm{Y} 2 \mathrm{Y}_{1}+\mathrm{e}_{2}$

Hasil perhitungan atau uji regresi dengan perhitungan SPSS ada dua macam hasil perhitungan regresi dan hasil perhitungan korelasi. 
Langkah berikutnya dalam penelitian ini adalah analisis regresi. Hal ini dimaksudkan untuk mengetahui pengaruh atau hubungan antar variabel secara gabungan dan secara terpisah (Priyatno, 2014).

\section{Tabel 3. Output Hasil Uji Analisis R Square}

\begin{tabular}{ccc}
\hline Model & $\mathbf{R}$ & R Square \\
\hline $\mathbf{1}^{\text {a }}$ & .796 & .633 \\
$\mathbf{2}^{\mathbf{b}}$ & .941 & .886 \\
\hline a. Predictors: (Constant), X2, X1; Dependent \\
Variable: Y1 \\
b. Predictors: (Constant), X2, X1; Dependent \\
Variable: Y1
\end{tabular}

Pada Tabel 3 (Model 1) dapat dilihat nilai R square terhadap variabel komitmen organisasional sebesar 0,633 yang artinya persentase pengaruh variabel iklim organisasi dan kemampuan kerja terhadap komitmen organisasional sebesar 63,3\%, sedangkan sisanya sebesar $36,7 \%$ dipengaruhi oleh variabel lain yang tidak dimasukkan dalam model dan error.

Pada Tabel 3 (Model 2) juga dapat dilihat bahwa nilai R square terhadap variabel kinerja pegawai sebesar 0,886 yang artinya persentase pengaruh variabel iklim organisasi, kemampuan kerja dan komitmen organisasional terhadap kinerja pegawai sebesar $88,6 \%$, sedangkan sisanya sebesar $11,4 \%$ dipengaruhi oleh variabel lain yang tidak dimasukkan dalam model dan error.

Pemeriksaan validitas model, terdapat dua indikator validitas model di dalam analisis jalur (path analysis), yaitu koefisien determinasi total dan theory triming. Nilai koefisien determinasi persamaan pertama di peroleh nilai sebesar 0,633 dan persamaan kedua 0,886 .

Regresi $1: P e_{1}=\sqrt{1-R_{1}^{2}}=\sqrt{1-0,633^{2}}=0,774$

Regresi $2: P e_{2}=\sqrt{1-R_{2}^{2}}=\sqrt{1-0,886^{2}}=0,5$

Sehingga koefisien determinasi total atau ketetapan model :

$R^{2} m=1-\left(P e_{1}^{2} x P e_{2}^{2}\right)$

$R^{2} m=1-\left(0,774^{2} \times 0,5^{2}\right)=1-0,1498=0,8502$

Dari hasil perhitungan diketahui keragaman data yang dapat dijelaskan oleh model analisis path tersebut adalah sebesar 0,8502 atau $85,02 \%$ dengan kata lain informasi yang terkandung dalam data $85,02 \%$ dapat dijelaskan oleh model tersebut. Sedangkan yang $14,98 \%$ dijelaskan oleh variabel lain yang belum terdapat dalam model dan error.

Uji validasi koefisien jalur pada setiap jalur untuk pengaruh langsung adalah sama dengan regresi. Berdasarkan theory triming, maka jalur-jalur yang tidak signifikan di buang, sehingga di peroleh model hasil penelitian yang didukung oleh data empirik. 
Nilai signifikan digunakan untuk menentukan hipotesis hubungan dari masing-masing jalur variabel, dapat dilihat pada Tabel 1 dan Tabel 2. Hipotesisnya berbunyi sebagai berikut:

$$
\begin{aligned}
& \mathrm{H}_{1}=\text { diterima, sig }=0,000 \text { lebih kecil dari } p \text {-value atau } \alpha=0,05 \\
& \mathrm{H}_{2}=\text { diterima, sig }=0,000 \text { lebih kecil dari } p \text {-value atau } \alpha=0,05 \\
& \mathrm{H}_{3}=\text { diterima, sig }=0,010 \text { lebih kecil dari } p \text {-value atau } \alpha=0,05 \\
& \mathrm{H}_{4}=\text { diterima, sig }=0,000 \text { lebih kecil dari } p \text {-value atau } \alpha=0,05 \\
& \mathrm{H}_{5}=\text { ditolak, sig }=0,207 \text { lebih besar dari } \mathrm{p} \text {-value atau } \alpha=0,05
\end{aligned}
$$

Pengujian dilakukan dengan membandingkan angka taraf signifikansi (Sig) hasil perhitungan dengan taraf signifikansi 0,05. Berdasarkan perhitungan angka signifikansi kurang dari 0,05 maka Hipotesis 1 sampai Hipotesis $4\left(\mathrm{H}_{1}-\mathrm{H}_{4}\right)$ diterima artinya ada hubungan linear antara iklim organisasi,kemampuan kerja, komitmen organisasional sedangkan Hipotesis $\left(\mathrm{H}_{5}\right)$ ditolak artinya tidak terdapat hubungan linier antara komitmen organisasional dengan kinerja pegawai. Diagram jalur hasil penelitian dapat dilihat pada Gambar 4. Untuk mengetahui pengaruh langsung antar variabel dapat dilihat pada Tabel 4.

Tabel 4. Pengaruh Langsung Antar Variabel

\begin{tabular}{clc}
\hline No & \multicolumn{1}{c}{ Rumus } & \multicolumn{1}{c}{ Hasil } \\
\hline 1 & Pengaruh langsung: & \\
& $\mathrm{X}_{1} \rightarrow \mathrm{Y}_{1}$ & $(0.507)^{2} \times 100 \%=25,70 \%$ \\
& $\mathrm{X}_{1} \rightarrow \mathrm{Y}_{2}$ & $(0.506)^{2} \times 100 \%=25,60 \%$ \\
2 & Pengaruh langsung: & \\
& $\mathrm{X}_{2} \rightarrow \mathrm{Y}_{1}$ & $(0.340)^{2} \times 100 \%=11,56 \%$ \\
& $\mathrm{X}_{2} \rightarrow \mathrm{Y}_{2}$ & $(0.411)^{2} \times 100 \%=16,89 \%$ \\
\hline
\end{tabular}

\subsection{Pengaruh Iklim Organisasi $\left(\mathrm{X}_{1}\right)$ Terhadap Komitmen Organisasional $\left(\mathrm{Y}_{1}\right)$}

Iklim organisasi berpengaruh positif dan signifikan terhadap komitmen organisasional. Hasil penelitian ini sesuai dengan hasil penelitian Suaraningsih, et al (2013) Pada penelitian ini menunjukkan iklim organisasi mendekati baik dengan nilai rata-rata 3,61, artinya persepsi pegawai tentang lingkungan organisasinya sudah cukup baik dan dapat mempengaruhi komitmen organisasional. Indikator iklim organisasi dengan nilai rata-rata paling tinggi $(4,16)$ adalah indikator struktur organisasi, hal ini dilihat dari tanggapan responden yang sebagian besar menyatakan struktur organisasi sudah sangat jelas.

Dengan adanya struktur yang jelas maka pegawai mempunyai tanggung jawab terhadap unit/bidang kerjanya. Jadi persepsi pegawai yang positif tentang struktur organisasinya dan dengan adanya pelimpahan tanggung jawab menyebabkan pegawai mempunyai kewajiban untuk tetap bertahan dalam organisasinya. 


\subsection{Pengaruh Iklim Organisasi $\left(\mathrm{X}_{1}\right)$ Terhadap Kinerja Pegawai $\left(\mathrm{Y}_{2}\right)$}

Hasil penelitian ini sesuai dengan teori Stringer (2002) yang menyatakan bahwa iklim organisasi berfokus pada persepsi-persepsi yang yang masuk akal atau dapat dinilai terutama yang memunculkan motivasi, sehingga mempunyai pengaruh langsung terhadap kinerja anggota organisasi. Wirawan (2008) juga menyatakan bahwa iklim organisasi mempengaruhi perilaku organisasi yang kemudian mempengaruhi kinerja anggota organisasi dan kemudian mempengaruhi kinerja organisasi.

Hasil terendah indikator iklim organisasi adalah penghargaan yang memiliki nilai rata-rata cukup $(3,13)$ yang berarti bahwa tanggapan responden sebagian besar menyatakan adanya penghargaan dari atasan terhadap hasil kerja yang dinilai baik, berupa pujian atau pengakuan dinilai cukup. Persepsi pegawai yang kurang menyenangkan tentang penghargaan terhadap hasil kerja dapat memberikan lingkungan kerja yang tidak kondusif dan dapat mempengaruhi kinerja pegawai.

Hal ini perlu mendapatkan perhatian atasan, penghargaan dalam bentuk pengakuan dapat meningkatkan rasa percaya diri pegawai terhadap hasil kerjanya dan pegawai akan merasa dihargai, dengan adanya pengakuan dari atasan diharapkan kinerja pegawai akan menjadi lebih baik lagi.

\subsection{Pengaruh Kemampuan Kerja $\left(\mathbf{X}_{2}\right)$ Terhadap Komitmen Organisasional $\left(\mathbf{Y}_{1}\right)$}

Hasil penelitian ini sesuai dengan teori yang dikemukakan oleh Dessler (1999), bahwa komitmen organisasional dapat dibangun didasarkan adanya kesempatan yang sama dalam mengaktualisasikan diri sesuai dengan kemampuan masing-masing. David dalam Minner (1997) juga mengemukakan bahwa diantara faktor yang mempengaruhi komitmen organisasional yaitu faktor personal, misalnya: usia, jenis kelamin, tingkat pendidikan, pengalaman dan lain lain.

Kemampuan pegawai menjabarkan program kerja ke dalam kegiatan-kegiatan maka secara langsung pegawai ikut terlibat dalam kegiatan yang dilakukan oleh Dinas Perindagkop dan UKM. Jadi, keterlibatan pegawai secara aktif dalam kegiatan-kegiatan yang ada di organisasi menyebabkan pegawai menjadi bagian dan mempunyai hubungan yang erat dengan organisasinya.

\subsection{Pengaruh Kemampuan Kerja $\left(\mathrm{X}_{2}\right)$ Terhadap Kinerja Pegawai $\left(\mathrm{Y}_{2}\right)$}

Hasil pengolahan data menyimpulkan bahwa hipotesis keempat ini dapat diterima. Hasil penelitian ini sesuai dengan teori Blumberg dan Prigle dalam Robbins (2006) dalam teori dimensi kinerja mengemukakan bahwa kinerja karyawan merupakan fungsi dari interaksi antara kemampuan (ability), motivasi (motivation), dan kesempatan (opportunity). 
Kemampuan pegawai menjabarkan program kerja ke dalam kegiatan-kegiatan maka dapat diartikan pegawai Dinas Perindagkop dan UKM mendukung keberhasilan pelaksanaan pekerjaan guna mendukung peningkatan kinerja organisasi. Semakin baik kemampuan seorang pegawai maka pencapaian kinerja pegawai akan lebih mudah dan dapat mempengaruhi pencapaian tujuan organisasi.

\subsection{Pengaruh Komitmen Organisasional $\left(\mathrm{Y}_{1}\right)$ terhadap Kinerja Pegawai $\left(\mathrm{Y}_{2}\right)$}

Dari hasil pengolahan data menggunakan program SPSS 22 menunjukan bahwa komitmen organisasional berpengaruh positif dan tidak signifikan terhadap kinerja pegawai dengan nilai beta 0,070 dan nilai signifikasi 0,207 yang berarti bahwa hipotesis tidak dapat diterima/ditolak.

Hasil penelitian ini, tidak sesuai dengan teori yang dikemukakan oleh Steers dan Porter (1983) yang menyatakan bahwa komitmen bukan hanya bersifat loyalitas yang pasif, tetapi juga melibatkan hubungan yang aktif dengan organisasi dan memiliki tujuan memberikan segala usaha demi keberhasilan organisasi.

\section{KESIMPULAN}

Berdasarkan hasil penelitian yang telah dilakukan, maka dapat Diambil bebeapa kesimpulan. Pertama, iklim Organisasi berpengaruh positif dan signifikan terhadap komitmen organisasional pegawai Disperindagkop dan UKM Kota Pontianak, pengaruh positif berarti dengan iklim organisasi yang meningkat maka semakin tinggi pula komitmen organisasional pegawai Disperindagkop dan UKM Kota Pontianak. Kedua, iklim organisasi Disperindagkop dan UKM berpengaruh positif dan signifikan terhadap kinerja pegawai, nilai positif berarti dengan iklim organisasi yang kondusif maka diharapkan meningkat pula kinerja pegawai Disperindagkop dan UKM. Ketiga, kemampuan kerja berpengaruh positif dan signifikan terhadap komitmen organisasional pegawai terhadap organisasinya, nilai positif berarti dengan kemampuan kerja yang meningkat maka komitmen organisasional pegawai terhadap Dinas Perindagkop dan UKM Kota Pontianak juga akan meningkat. Keempat, kemampuan kerja berpengaruh positif dan signifikan terhadap kinerja pegawai, nilai positif berarti semakin tinggi kemampuan kerja pegawai Disperindagkop dan UKM maka semakin tinggi pula nilai kinerja yang dihasilkan pegawai. Akhirnya, komitmen organisasional berpengaruh positif dan tidak signifikan dengan kinerja pegawai, hal ini kemungkinan disebabkan karena perpindahan atau mutasi pegawai di lingkungan pemerintahan kota Pontianak sering kali terjadi, sehingga menuntut pegawai dapat untuk siap ditempatkan dimana saja dan kapan saja sesuai dengan kebutuhan Pemerintah Kota Pontianak.

Keterbatasan dalam penelitian ini, yaitu penelitian ini hanya membahas pengaruh iklim organisasi dan kemampuan kerja terhadap komitmen organisasional dan 
dampaknya pada kinerja pegawai. Dimana, masih banyak faktor lain yang dapat mempengaruhi komitmen organisasional dan kinerja.

\section{DAFTAR PUSTAKA}

Abdullah, M. (2014). Manajemen dan Evaluasi Kinerja Karyawan. Yogyakarta: Aswaja Presindo.

Andryanto, M. (2014). Engaging Talents (Meningkatkan Kontribusi Karyawan secara strategis, Etis dan Bertanggung Jawab). Jakarta: Prasetya Mulya Publishing.

Dinas Perindagkop dan UKM Kota Pontianak. (2014). Rencana Strategis 2015-2019. Pontianak: Dinas Perindagkop dan UKM.

Dinas Perindagkop dan UKM Kota Pontianak. (2014). Laporan Kinerja Instansi Pemerintah 2014. Pontianak: Dinas Perindagkop dan UKM.

Drajat, I. (2014). Pengaruh Kemampuan Kerja dan Iklim Organisasi Terhadap Kinerja Pegawai. Jurnal Dinamika Manajemen, 2(3), 187 -196.

Dessler, G. (1999). Manajemen Sumber Daya Manusia (Jilid 2). Jakarta: PT. Dadi Kayana Abadi.

Oei, I. (2010). Riset Sumber Daya Manusia. Jakarta: Penerbit PT. Gramedia.

Luthans, F. (2006). Perilaku Organisasi (Ed. 10). Yogyakarta: Penerbit Andi.

Manthis, R. L. \& Jackson, J. H. (2001). Manajemen Sumber Daya Manusia. Jakarta: Penerbit Salemba Empat.

Thoha, M. (2003). Perilaku Organisasi, Konsep Dasar dan Aplikasinya. Jakarta: Raja Grafindo Persada.

Mangkunegara, A. P. (2011). Manajemen Sumber Daya Manusia Perusahaan. Bandung: Penerbit PT. Remaja Rosdakarya.

Surianingsih, N. L. P., Alamsyah, A. \& Thoyib, A. (2013). Pengaruh Iklim Organisasi terhadap Komitmen Organisasional dan Kinerja Karyawan di Rumah Sakit. Jurnal Aplikasi Manajemen, 11(2), 233 - 240.

Priyatno, D. (2014) SPSS 22 Pengolah Data Terpraktis. Yogyakarta: Penerbit Andi.

Republik Indonesia. (2014). Undang-Undang No. 5 tahun 2014 tentang Aparatur Sipil Negara (ASN). Jakarta : PT. Tamita Utama. 
Robbins, S. P. (2006). Perilaku Organisasi (Ed. 10). Jakarta: PT. Indeks.

Rofiatun, M. (2011). Pengaruh Iklim Organisasi dan Kompetensi Pegawai Terhadap Kinerja Pegawai dengan Mediasi Motivasi Pada Dinas-Dinas Di Kabupaten Kudus. Jurnal Analisis Manajemen, 5(1), 1-15.

Siagian, J. (2014). Metode Penelitian Sosial Praktis. Pontianak: STAIN Pontianak Press.

Suryana, C. E. Y., Mukhlis, A. (2015). Pengaruh Komitmen, Kompetensi, Motivasi dan Budaya Organisasi Terhadap Kepuasan Kerja serta dampaknya pada Kinerja Pegawai Badan Kesbangpol dan Linmas Aceh. Jurnal Manajemen, 4(2), 29-38.

Sugiyono. (2014). Metode Penelitian Manajemen. Bandung: PT. Alfabeta.

Solimun. (2012). Laboratorium Statistika FMIPA UB. Diakses dari http://fia.ub.ac.id/wp-content/uploads/2013/11/4-GSCA.pdf.

Sopiah. (2008). Perilaku Organisasi. Yogyakarta: PT. Andi.

Umar, H. (2004). Riset Sumber Daya Manusia. Jakarta: PT. Gramedia.

Wirawan. (2008). Budaya dan Iklim Organisasi. Jakarta: Salemba Empat.

Widodo, J. (2004). Membangun Birokrasi Berbasis Kinerja. Malang: Banyumedia Publishing. 